\title{
Forty Years of Sociology in Nigeria
}

\author{
Olufunmilayo Olorimtimehin, \\ Department of Sociology and Anthropology, Obafemi \\ Awolowo University,Ile-Ife
}

\section{Introduction}

Sociology as a discipline and profession in Nigerian has come a long way since its inception in 1960. The discipline has assumed a multi-disciplinary status view of the fact that it is taught in secondary and tertiary institutions and offered by students of economics, geography, political science, law, history, philosophy, medicine, engineering, agriculture etc. These disciplines recognize the relevance of sociology to the practice of their different professions.

Not surprising, sociology graduates are found all over the country as teachers in various secondary and tertiary institutions. Some of them are occupying medium and high cadres of the civil service at the Local, State and Federal levels. Others are in the private sector: - banking, manufacturing sectors, insurance companies, hospitals (both public and private) etc. Some are occupying high level positions in the armed forces and other related uniformed services such as the Police, Customs, Immigration, Prisons, Road Safety Corps etc. Some work in research institutions across the country while others are employed by non-governmental organizations. Yet, others are also employed in the religious sector not only as clergies or Muslim teachers but also as counsellors.

This piece focuses on the: (a) historical antecedents of the discipline and its pioneers in Nigeria; (b) development of sociology as a discipline and profession with reference to its paradigms and methodologies; (c) contributions of Nigerian sociology to national development and world scholarship; and (d) future of Nigerian sociology with reference to curricula development and capacity enhancement in the $21^{\text {st }}$ century. 


\section{Historical Antecedents}

The first University in Nigeria (viz., the University College, Ibadan) now known as the University of Ibadan was established in 1948. Before this time Nigerians travelled overseas most .especially to Britain and America in pursuit of higher education. The first Nigerian holder of a doctorate degree in sociology was Nathaniel Akinremi Fadipe who submitted a 1000 page dissertation entitled The Sociology of the Yoruba to the London School of Economics in 1939 (Okediji 1970). This was later developed into a book that was published by the University of Ibadan Press in 1970. Fadipe died in London in 1944.

Another Nigerian sociologist was Bankole Akpata who obtained the Ph. D. degree in Sociology from Charles University in Prague, Czechoslovakia in the early 1950s, Following these two pioneer Nigerian sociologists are the first generation of sociologists, who trained in British and North American Universities: the late Ademola Igun (Columbia and the New School), Akinsola Akiwowo (Boston), the late P.O. Okediji (Ottawa Kansas and Kansas), Oladejo Okediji (Columbia), Olatunde Oloko (Harvard), Mrs. B.A. Oloko (Harvard), T.O. Odetola (Rutgers), William Ogionwo (Lunds and Leeds), E.O. Akeredolu-Ale (London), the late Philip Olusanya (London), Onaolapo Soleye (Manchester), Simi Afonja (Birmingham), and Stephen Imoagene (Ibadan). Many of the first generation sociologists took up lectureship appointments in various Nigerian Universities. The influence of these pioneer teachers in sociology still persists particularly in the areas of curricula, theoretical, and methodological approaches.

Some foreign scholars like Peter C. Lloyd, a social anthropologist played a key role in the early years of the development of sociology at the University College, Ibadan. Lloyd was the first Head of Department of Sociology at Ibadan (1960-1964), followed by Ulf Himmelstrand, an eminent Swedish Sociologist who assumed the headship of Department between 
1964 and 1967. The latter nurtured sociology and was chiefly responsible for exposing young Nigerians to the new and interesting opportunities which the sociological enterprise offered. Himmelstrand was succeeded by the first indigenous Head of Department, the late P.O. Okediji who occupied this position between 1967 and 1976. He played a significant role in the establishment and expansion of undergraduate and postgraduate programmes. This was further enhanced during the tenure of Stephen Imoagene who succeeded him and held the position from 1976 to 1980. It is undeniable that the development of sociology in other Nigerian Universities was strongly influenced by the Sociology Department of University of Ibadan.

\section{Development of Sociology as a Discipline}

The first Department of Sociology in Nigeria was established at the University of Nigeria, Nsukka in 1960. Its curricula were greatly influenced by the American system. The Department of Sociology of the University of Ibadan was established as a fullfledged Department during the 1963/64 session under the headship of P.C. Lloyd (fourteen years after the establishment of the University as the University College (of London). Between 1960 and 1963 Sociology was a sub-department in the Faculty of Economics and Social Studies. The University of Ife (now Obafemi Awolowo University established its Department of Sociology and Anthropology in 1973. Prior to this time sociology and demography were in the same department. Since the 1960s, various tertiary institutions such as universities, polytechnics, and colleges of education have established departments and sub-departments for sociology. Some of these institutions like the universities or technology and agriculture teach sociology in their General Studies Department. At least 28 of Nigeria's Federal-, State- and privately-owned Universities have Departments of Sociology or maintain some aspects of the discipline as part for their curricula. 
The course content of sociology like other disciplines was initially determined by the respective Senate of the various institutions. However, about a decade ago, Nigeria's National Universities Commission based on the findings of its Accreditation Committee harmonised the curricula of disciplines in all Nigerian Universities in order to ensure uniformity. Minimum standards were set for all degree awarding programmes in the country. In essence, all programmes were re-organized and sociology like other disciplines now offers comparable courses at all levels in all institutions.

According to the National Universities Commission (N.U.C.) minimum standards, the core courses in sociology include history of social thought, sociological theory, and methods $<5 \mathrm{f}$ social research while there are other courses such as introduction to philosophy, logic, mathematics, and computer appreciation that are designed to develop the cognitive skills of students. The elective courses are wide-ranging and they focus on thematic areas like health, law, crime, industry, development, ethnic relations, religion, and the family. Every graduating student is also expected to submit a long essay that may be theoretical or empirical (Erinosho 1994).

The development of sociology as a discipline has been significantly enhanced by the establishment and activities of students' associations known as the Nigerian Sociological and Anthropological Association (NASA) in all the tertiary institutions where sociology is taught. The membership of these associations is in thousands across the country. In the various institutions where these associations exist, programmes are organized by members from time to time to create awareness among other students, members of the university community, and the general public about the subject matter, its contributions to national development, opportunities available to students of sociology, employment opportunities. Orientation programmes are held for new students at the beginning of each session, information on 
employment opportunities are made available to graduating students while lectures and seminars are held to create awareness among the generality of students about sociology as a discipline and profession. These efforts are geared towards creating a genuine basis for students to become interested in the discipline and to be motivated to become deeply involved in the profession. NASA holds annual meetings where decisions are taken on how to enhance the discipline. Decisions are also taken to ensure the contribution of sociology students to debates on national issues like democracy, poverty etc. and to suggest relevant solutions based on the knowledge generated from their discipline.

Another significant factor in the development of sociology as a discipline and particularly as a profession is the establishment of an association of sociologists. This association emanated from concern about the subject and the relevance of the paradigms that were nurtured in Britain and America to the Nigerian social environment. NASA which now consists twenty-two corporate and about 300 ordinary members, was established in 1971 (Erinosho 1994). Two of the principal objectives of the association are "to promote the application of social sciences in the formulation and the execution of socio-economic policies" and to "mobilize and orientate sociologists towards the liberation of Africa and other Third world peoples". The launching of NASA coincided with the first national conference at which the theme Sociology and Anthropology'-What for? was debated. This theme demonstrated the concern and dilemma which pioneer Nigerian sociologists faced. These concerns were reflected in the thrust of subsequent annual meetings of the association. The association was mainly preoccupied with themes related to decolonisation and development processes. The themes that provided the reference point through which Nigeria's post-colonial social structure and socio-economic conditions were analysed by the association include: Whither Nigerian Sociology? 
the Development of Africa (1975), Power in Contemporary Nigeria (1979), Mobilization of Human Resources for National Development (1981), Corruption in Development (1982), Strategies for Authentic Development in Nigeria (1987), Social Justice, National Development and the Third Republic (1989), Nigeria at Crossroads: Which Way Out (1995), and Challenges of

Sociology and Anthropology in Nigeria in the New Millennium (2000). Some of the proceedings of these meetings have been published and circulated amount libraries across the country.

One of the official organs of NASA is The Nigerian Journal of Anthropology and Sociology that was first published in September 1974. The issues of the journal appears from time to time depending on the availability of resources. Prior, to the launching of the journal, Nigerian sociologists relied on overseas journals and The Nigerian Journal of Economic and Social Studies (NJESS), founded in 1959. Over the years, various Nigerians provided outlets for scholarly papers. Such efforts invariably culminated in short-lived journals like The West Africa Journal of Sociology and Political Science edited by Justin Labinjoh that first appeared in 1976, A. Muyiwa Sanda's Nigerian Behavioural Sciences Journal (1978), and B.I.C. Ijomah's African Journal of Behavioral Sciences (1985) (Erinosho 1994). The survival of NASA until the present time has depended very much on the efforts of some indefatigable members particularly past and current leaders of the association: A. Akiwowo (Ile-Ife). Nzimiro (Nsukka), O. Otite (Ibadan), O. Onoge (Jos), the late J. A. Sofola (Ilorin), O. Erinosho (Ago-Iwoye), and A.I. Odebiyi (Ile-Ife). They have played significant roles in nurturing NASA up to the present state despite the dearth of resources and discretionary funding from responsible national authorities. 


\section{Orientation of Nigerian Sociology}

Sociology has developed many areas of specialization such as Industrial Sociology, Medical Sociology, Political Sociology, Sociology of Religion, Military Sociology, Sociology of Deviance, and Sociology of the Family, Gerontology, Sociology of Law, Urban Sociology and Gender Studies. Undergraduate and graduate students are trained in the different areas of specialization in the various Universities across the country. The contributions of sociologist span several areas of specialization, sociology of development, industrial sociology, ethnic relations, health, criminology, political sociology and demography. Work in these areas are in-depth, qualitative, quantitative reports. Such reports indicate a significant orientation towards empiricism, the influence of North American sociology where many Nigerian sociologists particularly the younger generation received their training.

The contributions of Nigerian sociologists also reflect diversity in theoretical orientations. Pioneer Nigerian sociologists were greatly influenced by structural functionalism. However, there were those who felt that structural functionalism legitimised colonialism, and inequalities and consequently limited the quest for revolutionary changes in society. Such sociologists opted for the Marxian theory as a more useful paradigm for analysing Nigerian society. To some extent, Nigerian sociology was very much a part of the debate which took place at the international level in the 1960s when there was a marked preoccupation with the appropriateness or otherwise of these dominant paradigms in the analysis of social structure.

The quest to achieve a 'Nigerian' sociology was spearheaded by Akinsola Akiwowo $1974 ; 1978 ; 1980 ; 1991)$ who worked assiduously for the indigenisation of sociology. He emphasized the need to chart a distinct and relevant path as well as disentangle Nigerian sociology from the schism resulting from 'Western paradigms'. This fervent nationalistic view point was given a further impetus at the symposium on Universalism and 
Indigenization of Sociological Theory that Akiwowo organized at the Xth World Congress of Sociology in Mexico City in 1982 whose proceedings were later published in a 1988 issue of International Sociology, 3 (2). Akiwowo's effort has not gone without being criticised for its limitations as a tool of sociological analyses particularly with regard to its lack of proper clarification of concepts (Lawuyi and Taiwo 1990).

I agree with Erinosho (1994) who conceded the desirability of indigenising themes and methods of sociological inquiry but thought it was probably premature to completely disengage Nigerian Sociology from mainstream sociological paradigms unless their irrelevance to the analysis of Nigeria's social structure as well as socioeconomic conditions can be wholly demonstrated. In any case, the original zeal and enthusiasm that heralded the concept of developing a 'Nigerian' sociology suffered set backs for certain reasons. The tempo of academic pursuits declined sine the 1980s due to political instability, bad governance, drastic cut in allocation of funds to the educational sector, and dissipation of efforts by scholars who shifted attention to non-academic pursuits, consultancy etc.

\section{Contributions of Nigerian Sociology}

The overall impact of sociology as a discipline in Nigeria can be assessed in relation to manpower development, research, governance, and international scholarship. It seems the most important among the foregoing, particularly in a rapidly developing society is sociology's contributions to manpower development. Thousands of sociology graduates are produced annually from the different universities in the country (see Appendix for the list of universities). While some of these graduates embark on postgraduate studies within and outside the country the rest are involved in careers in teaching, the civil service and the private sector.

As far as research is concerned Nigerian sociologists should 
be commended judging from the short span of the discipline in this county. Six subdisciplines-sociology of development, sociology of industry, sociology of deviance, sociology of health, demography, and gender studies feature prominently in local and international journals. Studies on population have, however enjoyed the most support from national and international funding agencies, mainly because of the perceived problems of population growth in the African sub-region. Gender studies are fast gaining ground with regard to funding by national and international funding agencies.

Nigerian sociologists provide service to governments at the Federal, State, and Local levels. For example, some sociologists have served in cabinets and as advisers to government functionaries. Some sociologists have assisted government in the formulation of policies on sectoral programmes in health, population activities, labour, gender issues, conflict resolution and social development. While the need for sociologists to contribute to governance in the ways already highlighted is fully appreciated, care must be taken not to allow such activities to adversely affect their contributions to the development of sociology as a discipline.

So far, the Nigerian government has avoided involving Nigerian sociologists as a distinct sub-group in the formulation and/or implementation of its programmes although the government is aware of the possible contributions of sociology to social development. The government also does not provide regular annual subvention to NASA nor does it lend political support, as has been the case with some other professional sub-groups in the social sciences. On their part, Nigerian sociologists are equally wary of being involved as a corporate entity in government programmes because of the strong fear that this would compromise their intellectual integrity.

Since the 1970s Nigerian sociologists have contributed significantly to world scholarship through participation in international congresses, conferences, symposia, seminars, work-shops etc. For example, sociologists from the different universities 
across the country are registered members of the International Sociological Association (ISA). Some of these members have over the years recorded their presence and active participation at the world congresses held in Sweden (1978), Mexico City (1982), India (1986), Madrid (1990), Bielefeld (1994), and Canada (1998). A number of Nigerian sociologists gained recognition at the international level - A. Akiwowo, Simi Afonja and Layi Erinosho were/are members of the Executive Board of the International Sociological Association (ISA) 1974-1982, 1986-90, and 1994-to-date respectively. Also O. Oloruntimehin and Femi Odekunle were members of the Executive Board of Research Committee on Deviance and Social Control (R.C. 29) of ISA (1974-78) and (1978-82) respectively while Layi Erinosho served as Executive Board Member of the Research Committee of the Sociology of Mental Health (1978-1986). The participation of these sociologists at the international level has tremendously enhanced the development of sociology as a discipline as well as a profession in Nigeria.

\section{The Future of Sociology}

So far, there has been a phenomenal interest in sociology as shown in the number of departments since 1960 (see Appendix). The number of students enrolling for degree and graduate programmes is increasing by the year. In addition, sociology has made significant in-roads into other disciplines particularly in the social sciences on the basis of the appreciation of its relevance. The liberalization economic programmes that have been introduced in the developing countries including Nigeria in the 80 s have severely limited the progress of sociology as a discipline. For example, the devaluation of currencies and the high level of inflation have made it more and more difficult for people who wish to study abroad to do so. Furthermore, many scholars cannot afford to spend their sabbatical abroad because of the cost of overseas travels while others cannot even attend local conferences, 
seminars, and workshops. This i\& because the cost of travel and upkeep abroad is prohibitively high relative to the personal incomes of scholars and their institutions can hardly provide them with the necessary funds. Thus the knowledge base of scholars in Nigeria and other developing countries is becoming more and more localised rather than broad and cosmopolitan.

For sociology to remain a virile discipline and profession in the $21^{\text {st }}$ century, special efforts should be made in certain important directions. Greater attention must be paid to adequate funding of university education. This is to ensure that adequate educational facilities such as libraries and quality materials (current books, journals, computerized documents) are available. Also there should be adequate funds for scholars to attend local and international congresses, conferences, seminars, symposia, workshops etc. Scholars who wish to spend their sabbatical leave abroad should be provided adequate funds either by their institutions or appropriate national and/or international agencies. Departments should be encouraged to review their programmes regularly (about five year period) to inject into them fresh curricula and new courses that would make the discipline relevant to the tempo of social development. Special efforts should be made to introduce courses that could facilitate capacity enhancement of sociologists in the 2 $3^{\text {st }}$ Century. To this end, courses that deal with new paradigms and methodologies as well as technological skills should be included in the curricula for undergraduate and postgraduate programmes.

\section{Concluding Remarks}

Sociology as a separate field of knowledge is relatively new in Nigeria, being established in 1960 after other social science disciplines like geography, economics, and political science. The main objective of the discipline is the systematic study of society, its structures, and functions. Scholars have over the years made significant contributions in the areas of teaching and research 
which are reflected in the establishment of Departments of Sociology in most of the Universities in Nigeria (federal, state, and private) and the existence of the thousands of sociologists employed in the pubic and private sectors of the economy. Nigerian sociologists have made appreciable impact in the area of scholarly publications that has enhanced their recognition in national and international scholarships.

The role of the Nigerian Sociological and Anthropological Students Association (NSASA) in promoting the status of sociology as a discipline within and outside the Universities is fully recognised. The Nigerian Sociological and Anthropological Association (NASA) has against all odds (political instability, financial constraints) contributed immensely to the development of sociology as a discipline and a profession. Indeed, the future direction of the discipline in this country depends to a considerable extent not only on the survival of the association but also on its ability to continue to play its role effectively in research and publication.

Funding is sine qua non in the expansion of the grounds so far covered by sociology as a discipline and profession. Thus the need for adequate funding of tertiary education by the government is strongly advocated. The need for the contributions of international funding agencies is also recognized.

\section{References}

Akiwowo, A. (1974) "Contemporary Sociology in Nigeria” in R.P. Mohun and D. Martindale (eds.) Handbook of Contempo-rary Development in World Sociology, Beverly Hills: Sage Publications.

Akiwowo, A. (1978) "Ajobi and Ajogbe: Variations on the Theme of Sociation" Inaugural Lecture Series, 46, University of Ife (now Obafemi Awolowo University), lleIfe, Nigeria. 
Akiwowo, A. (1980) "Sociology in Africa Today", Current Sociology, Vol.28, No. 2 (Summer), 55-72.

Akiwowo, A. (1991) "Responses to Lawuyi and Taiwo", International Sociology, Vol. 6, No.2, (June), 243-251.

Erinosho, O. (1994) "Round Table on Nigerian Sociology -Thirty- Three Years of Sociology in Nigeria", International Sociology, Vol. 9, No. 2 (June), 209216.

Fadipe, N.A. ed. (1970) The Sociology of the Yoruba, Ibadan: University Press.

Lawuyi, O.B. and Taiwan O. (1990) "Toward an African Sociological Tradition: A Rejoinder to Akiwowo and Makinde", International Sociology, Vol. 5, No. 1, 57-73.

Okediji, P.O. (1970) "Introduction" in Fadipe, N.A. (ed.) Sociology of the Yoruba, Ibadan: University Press.

Other Documents

University of Ibadan, Department of Sociology Hand Book 1993, International Sociological Association (ISA) news Bulletin 1978 and 1994.

Deviance and Social Control (Research Committee No. 29)

Newsletter 1974 and 1978)

\section{Appendix}

List of Nigerian Universities where Sociology and Anthropology Courses are taught

\section{Federal Universities:}

Ahmadu Bello University, Zaria

University of Abuja, Abuja

Bayero University, Kano

University of Benin, Benin City

University of Calabar, Calabar

University of Ibadan, Ibadan

University of Jos, Jos

University of Ilorin, Ilorin 
University of Lagos, Lagos

University of Maiduguri, Maiduguri

Nnamdi Azikwe University, Awka

Obafemi Awolowo University, Ile-Ife

University of Port-Harcourt, Port-Harcourt

Usmanu Danfodiyo University, Sokoto

University of Nigeria, Nsukka

University of Uyo, Uyo.

\section{State Universities:}

Abia State University, Uturu

Benue State University, Markudi

Delta State University, Abraka

Ambrose AH University, Ekpoma

Imo State University, Owerri

Lagos State University, Ojoo, Lagos

Ogun State University, Ago-Iwoye

University of Ado-Ekiti, Ado-Ekiti

Ondo State University, Akungba

Enugu State University of Science and Technology, Enugu.

\section{Private Universities:}

Igbinedion University, Okada, P.M.B. 006, Benin City

Madonna University, P.O. Box 47, Okija, Anambra State

Source: Joint Admission and Matriculation Board, 1999 